\title{
Effects of adiponectin and leptin co-treatment on human breast cancer cell growth
}

\author{
KATAI J. NKHATA, AMITABHA RAY, TODD F. SCHUSTER, \\ MICHAEL E. GROSSMANN and MARGOT P. CLEARY \\ Hormel Institute, University of Minnesota, 801 16th Avenue NE, Austin, MN 55912, USA
}

Received January 23, 2009; Accepted March 19, 2009

DOI: $10.3892 /$ or_00000395

\begin{abstract}
Obesity is a risk factor for postmenopausal breast cancer (BC), but the specific mechanisms for this relationship are not well understood. Studies on adipocyte-derived adiponectin and leptin reveal opposing effects on BC cell proliferation in vitro, suggesting they may play a role in $\mathrm{BC}$ pathogenesis. In the current study we examined effects on proliferation of five $\mathrm{BC}$ cell lines treated with varying adiponectin:leptin $(\mathrm{A} / \mathrm{L})$ ratios. A decrease in proliferation was noted for MCF-7 and T47-D cells with increasing ratios (2-500), while an increase was seen in similarly treated MDA-MB-231 and MDA-MB-361 cells. For SK-BR-3 cells, an increase was seen at a ratio of 8 . We identified differential effects on some pro-mitogenic, survival and apoptosis-related proteins in MCF-7 and T47-D cells treated at an A/L ratio of 100. Specifically, the AKT and MAPK pathways were not activated in MCF-7 cells, but AKT activation occured within $30 \mathrm{~min}$ and MAPK activation was sustained at $48 \mathrm{~h}$ in T47-D cells. p53 and Bax were elevated in MCF-7, but were below basal in T47-D cells at $30 \mathrm{~min}$. While co-treatment enhanced apoptosis in MCF-7, similar treatment had the opposite effect in T47-D cells. There were no differences in cell cycle distribution between treated or untreated MCF-7 or T47-D, although T47-D cells had a slightly higher proportion in the G1/G0 phase after co-treatment. The effects of $\mathrm{A} / \mathrm{L}$ ratio on mediating proliferation may have some specificity since the cell lines exhibited different responses. This may explain previous inconsistencies for the relationship of serum leptin with BC. More studies are needed to better understand the complex interactions that exist between these two adipokines.
\end{abstract}

\section{Introduction}

Obesity is a well recognized risk factor for postmenopausal breast cancer but the specific mechanisms underlying this

Correspondence to: Dr Margot P. Cleary, Hormel Institute, University of Minnesota, 801 16th Avenue NE, Austin, MN 55912, USA

E-mail: mpcleary@hi.umn.edu

Key words: adiponectin, leptin, obesity, breast cancer, adipokines relationship are not fully understood. It has been postulated that peripheral aromatization of androgens in expanded adipose tissue depots leads to elevated estrogen levels and also to a decreased level of sex hormone binding globulin $(1,2)$. This would result in more biologically available estrogen which may be how obesity contributes to the pathogenesis of hormone-responsive breast cancer. With the recognition of adipose tissue as an active endocrine organ, and not merely a storage depot, the role of adipocyte-derived hormones are also being investigated to provide additional and/or complementary mechanistic explanations for the observed increased risk of breast cancer in obese postmenopausal women.

Adipose tissue secretes a number of cytokine-like proteins collectively termed adipokines that have been directly or indirectly implicated in breast cancer pathogenesis. For example, TNF- $\alpha$ and IL-6 are known to act in either an autocrine or paracrine manner to stimulate estrogen biosynthesis by production of aromatase $(2,3)$. Furthermore, studies of the adipokines leptin and adiponectin, suggest that direct effects of these two proteins in obese postmenopausal women may enhance breast cancer development, as recently reviewed by Vona-Davis and Rose (4).

Leptin is a $16-\mathrm{kDa}$ protein whose concentration in the blood is directly correlated to body fat mass or body weight, and is thus found to be elevated in obesity. Since its identification by Friedman and colleagues in 1994 (5), leptin has been shown to be multi-functional, as demonstrated in its effects on satiety control, body weight regulation, energy expenditure, immune function and reproduction (6-8). In addition, preclinical studies from our laboratory demonstrated a role for leptin in mammary tumor development as evidenced by the fact that mice deficient in leptin $\left(\operatorname{Lep}^{\mathrm{ob}} \mathrm{Lep}^{\mathrm{ob}}\right)$, or with non-functioning leptin receptors $\left(\operatorname{Lepr}^{\mathrm{db}} \mathrm{Lepr}^{\mathrm{db}}\right)$ did not develop transgene-induced mammary tumors $(9,10)$. Leptin's functions are mediated via the signaling-competent long form of the leptin receptor $(\mathrm{ObRb})$, which is ubiquitously expressed by many tissues including tumor cell lines (11).

Adiponectin on the other hand, is a $30-\mathrm{kDa}$ protein that is very abundant in the blood of normal weight individuals, but it is paradoxically reduced in obesity and is thus generally found to be negatively correlated to body fat mass. Expressed primarily in white adipose tissue, adiponectin has antiinflammatory, anti-diabetic and anti-atherogenic functions, and plays a role in modulation of endothelial function and suppression of the process of angiogenesis (3). Adiponectin's effects appear to be mediated through two known receptors, 
AdipoR1 and AdipoR2. AdipoR1 is a high-affinity receptor for the globular form of adiponectin, but also has a very low affinity for the full length molecule and is expressed ubiquitously. It is most abundant in skeletal muscle, but is also present in endothelial cells and other tissues. AdipoR2 has intermediate affinity for both forms of adiponectin and is predominantly expressed in the liver. Many tumor cell lines including those derived from the breast also express one or both receptors $(12,13)$.

Several laboratories including our own, have demonstrated opposing effects of leptin and adiponectin when tested separately on breast cancer cell proliferation. Specifically, we and others have shown that the addition of leptin enhances proliferation of breast cancer cells in vitro (14-17), while addition of adiponectin has anti-proliferative effects $(18,19)$. In a preliminary investigation, we found that the ratio of adiponectin:leptin impacted estrogen receptor positive and negative human breast cancer cells differently (20). Although the ratio of adiponectin and leptin together has not been extensively studied for effects on breast cancer cell proliferation, signaling and apoptosis, a recent human study reported a higher leptin:adiponectin ratio in women with breast cancer who also had reduced serum adiponectin levels (21). These findings led us to hypothesize that the balance in the levels of adiponectin and leptin may be an important regulator of breast cancer cell growth and would provide an explanation for how obesity is related to this disease. Here, we present results of an in-depth investigation of the interaction of adiponectin and leptin on a number of human breast cancer cell lines.

\section{Materials and methods}

Proliferation assays of five different breast cancer cell lines. Three ER-positive (MCF-7, T47-D and MDA-MB-361) and two ER-negative (MDA-MB-231 and SK-BR-3) cell lines were obtained from the American Type Culture Collection (ATCC, Manassas, VA). The cells were grown in ATCC recommended culture medium to about $70 \%$ confluency, harvested and counted with a coulter counter. Cells were then plated at a density of 5000 cells per well in 96-well plates and allowed to attach for $20-24 \mathrm{~h}$ at $37^{\circ} \mathrm{C}$, after which complete medium was carefully removed and replaced with serum-free medium. The plates were returned to the incubator for an additional 20-24 h for cells to reach quiescence. Treatments with both human recombinant adiponectin (Acrp30, full length, R\&D Systems, Minneapolis, MN) and leptin (Cell Sciences, Canton, MA) were performed, at concentrations deemed to represent physiologic levels, i.e. 10,25 and $50 \mathrm{ng} / \mathrm{ml}$ for leptin and 5000 and $1000 \mathrm{ng} / \mathrm{ml}$ for adiponectin (we also included the lower concentrations of 100,200 and $500 \mathrm{ng} / \mathrm{ml}$ ). The cells were treated for $48 \mathrm{~h}$ after which proliferation assays were performed using the commercially available Cell Counting Kit-8 Assay (Dojindo Molecular Technologies, Gaithersburg, MD). In this assay, a formazan dye is generated by the activity of dehydrogenases in cells that is directly proportional to the number of living cells. Dual optical densities were measured at 450 and $620 \mathrm{~nm}$. The experiments were performed in triplicate at a minimum for each cell line with 6 replicates at each test point.
Preparation for Western blots. For Western blot analyses, two of the cell lines (MCF-7 and T47-D) were plated in 6-well plates at a density of $1 \times 10^{6}$ cells/well and allowed to attach for about $24 \mathrm{~h}$. The cells were serum-starved for $24 \mathrm{~h}$ and then treated with $50 \mathrm{ng} / \mathrm{ml}$ leptin, $5000 \mathrm{ng} / \mathrm{ml}$ adiponectin or a combination of the two adipokines for 30 min or $48 \mathrm{~h}$. Protein extraction was performed using the Mammalian Cell, PE LB ${ }^{\mathrm{TM}}$ Kit (Genotech, St. Louis, MO) containing EDTA, DTT and protease inhibitors. Cell lysates were sonicated and subsequently centrifuged at $13000 \mathrm{rpm}$ for $10 \mathrm{~min}$ at $4^{\circ} \mathrm{C}$, and clear supernatants were collected. For the Western blot analyses, 10\% SDS-PAGE was used and proteins were transferred to PVDF membranes (Immobilon, P, Millipore, Billerica, MA). Primary antibodies against the following proteins were used for probing: Ob-Rb (Linco, St. Louis, MO), Ob-R, AdipoR1, AdipoR2, AMPK- $\alpha$, Stat3, p-Stat3, PCNA (Abcam, Cambridge, MA), cyclin D1, Bcl-xL, Bax, p53, MCL-1, caspase 3, caspase 6, caspase 9 (Santa Cruz, CA), AKT, p-AKT (Thr308), p44/42 MAPK, and p-p44/42 MAPK (Cell Signaling, Danvers, MA). Suitable secondary IgGs conjugated with alkaline phosphatase (AP) were used as the secondary antibody. Proteins were detected by enhanced chemifluorescence (ECF substrate, Amersham, Newark, NJ) and developed in a Storm 840 system (Amersham, Piscataway, NJ). Bands were quantified with Un-Scan-It gel version 6.1 digitizing software (Silk Scientific, Orem, UT).

Preparation for flow cytometry. MCF-7 and T47-D cells were cultured in T-25 flasks at a density of $6 \times 10^{5}$ cells/flask and allowed to attach for $24 \mathrm{~h}$. The cells were serumdeprived for an additional $24 \mathrm{~h}$ before adipokine treatments or co-treatments for $48 \mathrm{~h}$. Flow cytometry was performed as detailed below.

Flow cytometry analysis of the cell cycle. Cells were harvested with $0.025 \%$ trypsin +5 mM EDTA in PBS. After washing with PBS, the cells were re-suspended in $0.4 \mathrm{ml}$ of PBS and $1 \mathrm{ml}$ of ice-cold absolute ethanol was added and mixed immediately. Cells were fixed at $-20^{\circ} \mathrm{C}$ for a minimum of $2 \mathrm{~h}$ and then washed with PBS. Cells were incubated with $20 \mu \mathrm{g} /$ $\mathrm{ml}$ propidium iodide and $200 \mu \mathrm{g} / \mathrm{ml}$ RNAase for $30 \mathrm{~min}$ at room temperature in the dark. Cells were analyzed on a Becton-Dickinson FACSCalibur flow cytometer (BD Biosciences, San Jose, CA). Intact cells were gated in the FSC/SSC plot to exclude small debris. Cell cycle was determined using ModFit LT software (Verity Software House, Inc., Topsham, ME).

Flow cytometry analysis of apoptosis. Apoptosis was evaluated using the Annexin V-FITC Apoptosis Detection Kit (MBL International Corp., Watertown, MA). Cells were harvested with $0.025 \%$ trypsin +5 mM EDTA in PBS, and $2.5 \%$ FBS in PBS was added as soon as the cells were released from the dish. Then the cells were transferred to a centrifuge tube, washed with PBS and incubated for $5 \mathrm{~min}$ at room temperature with Annexin V-FITC plus propidium iodide (PI) according to the manufacturer's protocol included in the kit. Cells were analyzed on a Becton-Dickinson FACSCalibur flow cytometer (BD Biosciences, San Jose, CA), placing the FITC signal in 


\section{A. $\underline{\text { MCF-7 }}$}

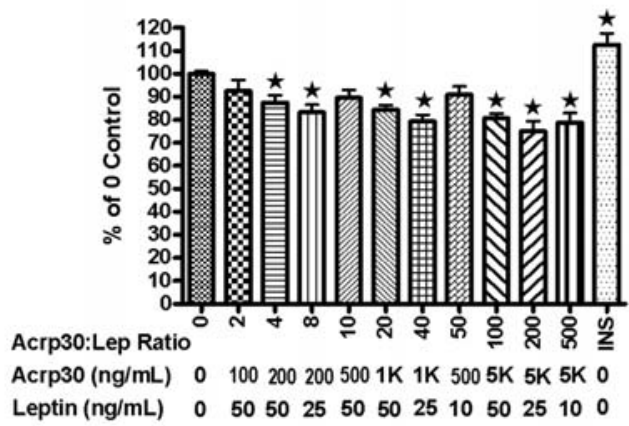

C. MDA-MB-231

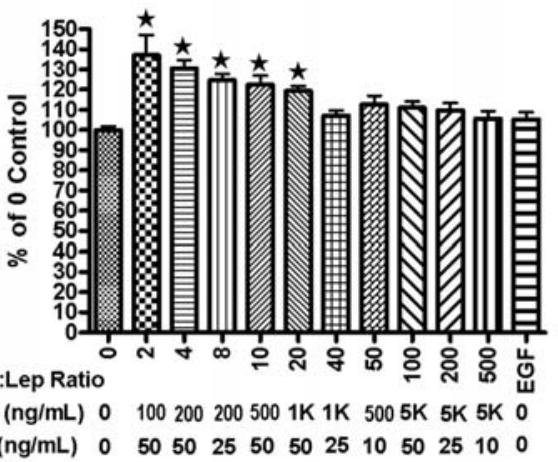

\section{B. T47-D}

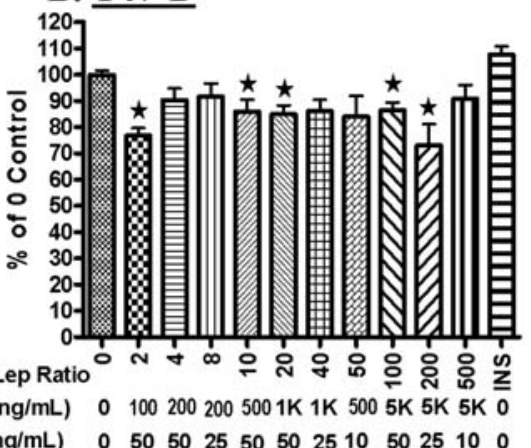

\section{D. $\underline{\text { SK-BR-3 }}$}

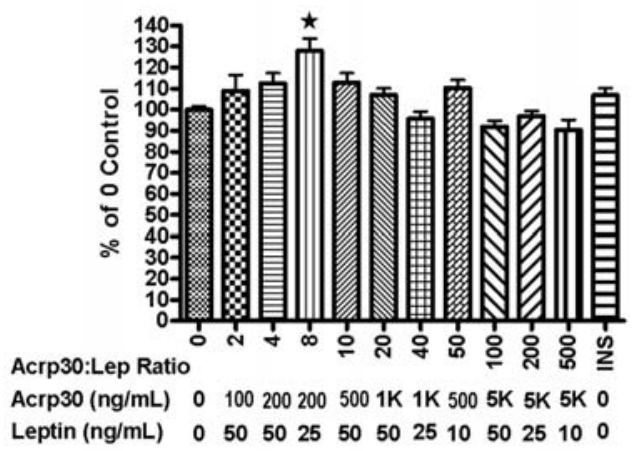

\section{E. MDA-MB-361}

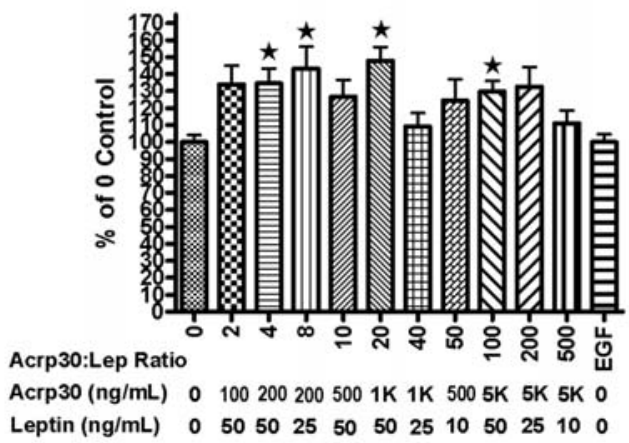

Figure 1. Cell proliferation assays of 5 breast cancer cell lines after treatment with $10-50 \mathrm{ng} / \mathrm{ml}$ leptin in the presence of $100 \mathrm{ng} / \mathrm{ml}$ to $5 \mu \mathrm{g} / \mathrm{ml}$ adiponectin (Acrp30) for $48 \mathrm{~h}$. The co-treatment experiments were repeated a minimum of 3 times for each cell line, with 6 replicates at each test point. (A) For MCF-7 ANOVA $\mathrm{P}<0.0001$ with Dunnett's test $\mathrm{P}<0.05$ for 0 vs. ratio of 4 and 8 , and $\mathrm{P}<0.01$ for 0 vs. ratio of 20, 40, 100, 200 and 500. (B) For T47-D ANOVA $\mathrm{P}<0.0001$ with Dunnett's test $\mathrm{P}<0.01$ for 0 vs. ratio of 2,20 or 200 , and $\mathrm{P}<0.05$ for 0 vs. ratio of 10 or 100 . (C) For MDA-MB-231 ANOVA $\mathrm{P}<0.0001$ with Dunnett's test $\mathrm{P}<0.01$ for 0 vs. ratio of 2, 4, 8, 10 and 20. (D) For SK-BR-3 ANOVA $\mathrm{P}<0.001$ with Dunnett's test $\mathrm{P}<0.01$ for 0 vs. ratio of 8 . (E) For MDAMB-361 ANOVA $\mathrm{P}<0.0001$ with Dunnett's test $\mathrm{P}<0.01$ for 0 vs. ratio of 4,8 and 20 , and $\mathrm{P}<0.05$ for 0 vs. ratio of 100 . $(1 \mathrm{~K}, 5 \mathrm{~K}=1$ or $5 \mu \mathrm{g} / \mathrm{ml}$ Acrp30, respectively; INS $=2 \mu \mathrm{M}$ insulin; $\mathrm{EGF}=10 \mathrm{ng} / \mathrm{ml}$ epidermal growth factor).

FL1 and the PI signal in FL2. Intact cells were gated in the FSC/SSC plot to exclude small debris. Cells in the lower right quadrant of the FL1/FL2 dot plot (labeled with Annexin V-FITC only) are considered to be in early apoptosis, and cells in the upper right quadrant (labeled with Annexin V-FITC and PI) are in late apoptosis/necrosis.

Statistical analyses. One-way ANOVA with Dunnett's post test was performed where appropriate using GraphPad Prism version 4.00 (GraphPad Software, San Diego, CA) with significance accepted at $\mathrm{P}<0.05$.

\section{Results}

Effects of leptin and adiponectin on breast cancer cell proliferation. The proliferation assays indicated that increasing the adiponectin:leptin $(\mathrm{A} / \mathrm{L})$ ratio resulted in down-regulation of proliferation of MCF-7 and T47-D cells across all the ratios tested (2-500). The reduction in cell numbers was significant compared to untreated cells at most of these ratios (Fig. 1A and B). Notably, MCF-7 cells appeared more responsive to this inhibition compared to T47-D cells. By contrast, in MDA-MB-231 cells, altering the $\mathrm{A} / \mathrm{L}$ ratio in an identical 
A. $\underline{\text { MCF-7 }}$

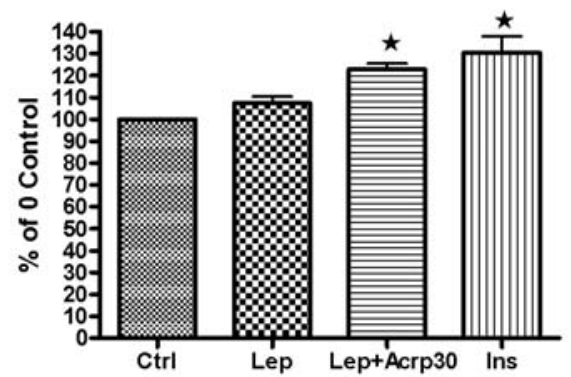

B. T47-D

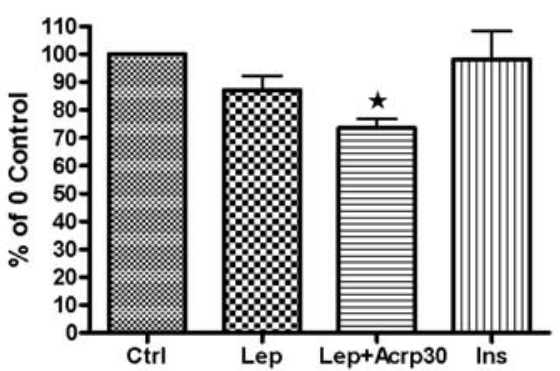

Figure 2. Flow cytometry assessment of total apoptosis increase over untreated controls in (A) MCF-7 and (B) T47-D cells after treatment with 50 ng/ml leptin (Lep) alone or in combination with $5 \mu \mathrm{g} / \mathrm{ml}$ adiponectin (Acrp30) for $48 \mathrm{~h}$ in serum-free medium. Insulin (Ins) (10 $\mu \mathrm{g} / \mathrm{ml})$ was used as a positive control. The experiments were repeated a minimum of 3 times for each treatment or control. Asterisks represent significantly higher apoptosis in MCF-7 cells with adipokine co-treatment and insulin (ANOVA $\mathrm{P}=0.0028$ ), and significantly lower apoptosis in T47-D cells with adipokine co-treatment (ANOVA $\mathrm{P}=0.0393)$.

fashion (2-500) did not result in a decrease in cell numbers compared to untreated cells. In fact, at lower ratios of these adipokines (2-20) there were significantly increased cell numbers compared to untreated cells, while higher ratios (40-500) resulted in cell proliferation that was not significantly different from untreated cells (Fig. 1C). For SK-BR-3 cells, lower $\mathrm{A} / \mathrm{L}$ ratios appeared to enhance cell proliferation peaking at a ratio of 8 (i.e., $200 \mathrm{ng} / \mathrm{ml}$ adiponectin in the presence of $25 \mathrm{ng} / \mathrm{ml}$ leptin) where a significantly higher number of cells relative to untreated control was observed (Fig. 1D). A higher ratio of these adipokines appeared to suppress proliferation, but this was not significant. For MDAMB-361 cells, the effect of altering the A/L ratio appeared to be opposite from that observed in MCF-7 and T47-D cells in that cell numbers were enhanced across the ratios tested (2-500), with some significant increases observed within this spectrum (Fig. 1E).

Effects of leptin and adiponectin on apoptosis in MCF-7 and T47-D cells. Based on the observation that MCF-7 cells displayed a more robust response to adipokine co-treatment compared to T47-D cells in the proliferation assays, we conducted additional experiments on these two ER-positive cell lines to examine apoptosis as well as probe for signaling and apoptosis-related proteins, including effects on the cell cycle. Concentrations of $50 \mathrm{ng} / \mathrm{ml}$ for leptin and $5000 \mathrm{ng} / \mathrm{ml}$ for adiponectin (a ratio of 100 when both were used together) were chosen to represent levels that would be found in an obese person and were used for the treatments and cotreatments in these additional experiments.

MCF-7 cells demonstrated little change in apoptotic response following $50 \mathrm{ng} / \mathrm{ml}$ leptin treatment for $48 \mathrm{~h}$ in serum-free medium, as assessed by flow cytometry (Fig. 2A). This response was enhanced in the presence of both $50 \mathrm{ng} / \mathrm{ml}$ leptin and $5000 \mathrm{ng} / \mathrm{ml}$ adiponectin and was significantly higher than the response observed in untreated cells (Fig. 2A). The insulin treatment control also exhibited greatly enhanced apoptosis in MCF-7 cells (Fig. 2A). In contrast, an apoptosis rate lower than untreated cells was observed in T47-D cells treated with $50 \mathrm{ng} / \mathrm{ml}$ leptin alone, and this apoptosis rate was significantly reduced in the presence of both adipokines (Fig. 2B).
Effects of leptin and adiponectin on cell signaling and apoptosis-related proteins in MCF-7 and T47-D cells. We next examined the effects of adipokine treatment or cotreatment on the pro-mitogenic (MAPK) and pro-survival (AKT) pathways as well as on apoptosis-related proteins p53, Bax and Bcl-xL in MCF-7 and T47-D cells. In MCF-7 cells, activated MAP Kinase (p-p42/44 MAPK) was barely detectable with leptin-only treatment (0.3-fold of basal), although the levels of this protein appeared to be restored to basal levels with co-treatment after $48 \mathrm{~h}$ (Fig. 3A). By contrast in T47-D cells with leptin-only treatment, we detected activated p42/44 MAPK that was almost 3-fold higher than the control level at $48 \mathrm{~h}$. The activation of p42/44 MAPK was further enhanced in the presence of leptin with the addition of $5000 \mathrm{ng} /$ $\mathrm{ml}$ adiponectin (3.5-fold) in T47-D cells after $48 \mathrm{~h}$ treatment (Fig. 3B).

Activated AKT (Thr 308) levels were below basal levels with leptin-only treatment after $30 \mathrm{~min}$ in MCF-7 cells, and much lower with co-treatment (0.3-fold of control). The levels of this protein in MCF-7 cells remained low after co-treatment at $48 \mathrm{~h}$ (Fig. 3A). Conversely, activated AKT (Thr 308) was detectable in T47-D cells after 30 min of leptin-only treatment (3.6-fold higher than control), and the levels of this protein were equally high with co-treatment (3.1-fold) at $30 \mathrm{~min}$. Activated AKT levels returned to below basal levels by $48 \mathrm{~h}$ in T47-D cells (Fig. 3B).

In MCF-7 cells higher p53 levels than control were detectable with leptin-only and adiponectin-only treated cells within $30 \mathrm{~min}$ (4.6- and 5.6-fold, respectively), as well as with co-treatment (4.1-fold) (Fig. 3A). p53 levels were lower than control in T47-D cells after co-treatment (Fig. 3B).

Bax protein levels that were 1.8- and 1.7-fold higher relative to control were detectable in MCF-7 cells $30 \mathrm{~min}$ after leptin-only or adipokine co-treatment, respectively (Fig. 3A), but these returned to below basal at $48 \mathrm{~h}$. Levels of Bax protein were down-regulated both with leptin-only treatment and adipokine co-treatment at $48 \mathrm{~h}$ in T47-D cells (Fig. 3B). Levels of Bcl-xL protein in MCF-7 cells were almost 3-fold higher at $30 \mathrm{~min}$ with leptin, adiponectin or combination treatment, but these were below basal at $48 \mathrm{~h}$ (Fig. 3A). Similarly, in T47-D cells levels of Bcl-xL protein were higher in adipokine co-treated cells than control cells at 
A.

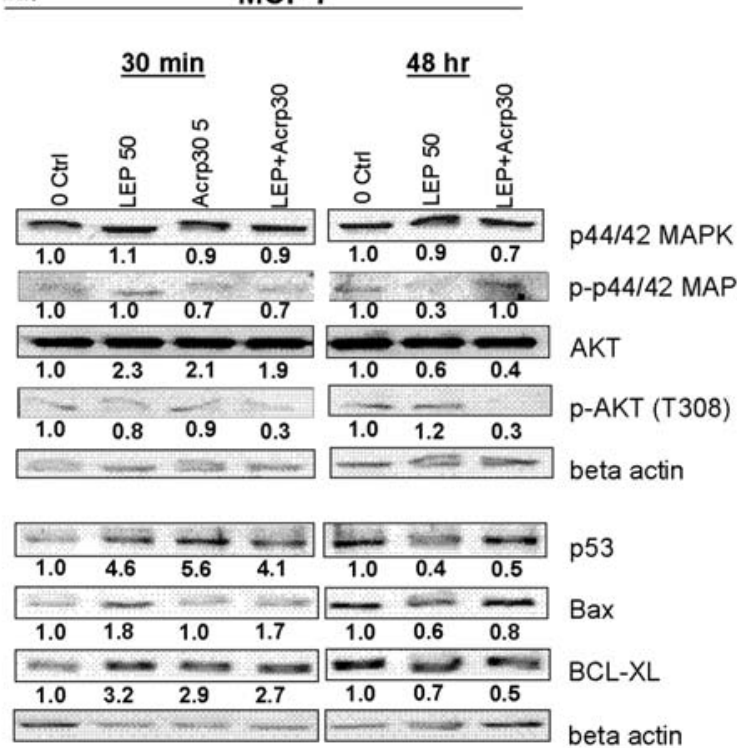

B.

T47-D

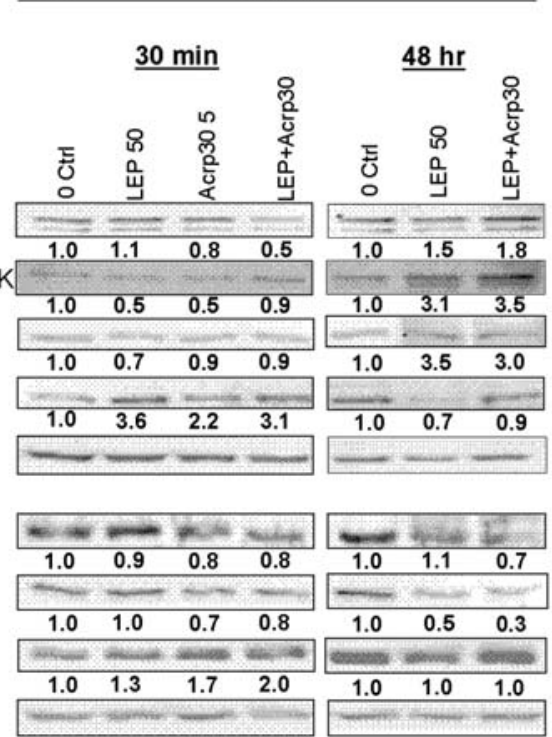

Figure 3. Representative Western blot analyses of MCF-7 and T47-D cells treated with $50 \mathrm{ng} / \mathrm{ml}$ leptin (LEP50), $5 \mu \mathrm{g} / \mathrm{ml}$ adiponectin (Acrp30 5) or a combination of leptin and Acrp30 for $30 \mathrm{~min}$ or $48 \mathrm{~h}$. Numeric values represent arbitrary densitometry units corrected for B-actin and relative to controls at each time-point. Experiments were repeated twice. MAPK, AKT and their activated forms, p53, Bax and Bcl-xL are shown.

Table I. Effects on signaling and apoptosis-related proteins.

\begin{tabular}{|c|c|c|c|c|c|}
\hline \multirow[b]{3}{*}{ Protein } & \multirow[b]{3}{*}{ Treatment } & \multicolumn{4}{|c|}{ Cell line } \\
\hline & & \multicolumn{2}{|c|}{ MCF-7 } & \multicolumn{2}{|c|}{ T47-D } \\
\hline & & $30 \mathrm{~min}$ & $48 \mathrm{~h}$ & $30 \mathrm{~min}$ & $48 \mathrm{~h}$ \\
\hline \multirow[t]{3}{*}{ p-p44/42 MAPK } & Leptin & Basal & -- & -- & ++ \\
\hline & Acrp30 & - & NT & -- & NT \\
\hline & Leptin+Acrp30 & - & Basal & - & +++ \\
\hline \multirow[t]{3}{*}{ p-AKT (Thr308) } & Leptin & - & + & +++ & - \\
\hline & Acrp30 & - & NT & ++ & NT \\
\hline & Leptin+Acrp30 & -- & -- & ++ & - \\
\hline \multirow[t]{3}{*}{ p53 } & Leptin & +++ & -- & - & + \\
\hline & Acrp30 & ++++ & NT & - & NT \\
\hline & Leptin+Acrp30 & +++ & -- & - & - \\
\hline \multirow[t]{3}{*}{ Bax } & Leptin & ++ & - & Basal & -- \\
\hline & Acrp30 & Basal & NT & - & NT \\
\hline & Leptin+Acrp30 & ++ & - & - & -- \\
\hline \multirow[t]{3}{*}{ Bcl-xL } & Leptin & +++ & - & + & Basal \\
\hline & Acrp30 & ++ & NT & ++ & NT \\
\hline & Leptin+Acrp30 & ++ & -- & +++ & Basal \\
\hline
\end{tabular}

Summary of effects on cell signaling and apoptosis-related proteins in MCF-7 and T47-D cells after adipokine treatments or co-treatments for 30 min or $48 \mathrm{~h}$. NT, not tested; Basal, protein levels similar to untreated control; +, increase in protein levels above basal; -, decrease in protein levels below basal. Leptin $=50 \mathrm{ng} / \mathrm{ml}$; Acrp30 $=5 \mu \mathrm{g} / \mathrm{ml}$. The number of signs denotes the magnitude of the increase or decrease.

$30 \mathrm{~min}$ (2-fold), but these levels were back to basal at $48 \mathrm{~h}$ (Fig. 3B).

The effects on representative cell signaling and apoptosisrelated proteins following adipokine treatment and cotreatment on MCF-7 and T47-D cells are summarized in Table I.
Influence of leptin and adiponectin on cell cycle in MCF-7 and T47-D cells. Lastly, we examined the effects on cell cycle distribution of MCF-7 and T47-D cells after treatment with $50 \mathrm{ng} / \mathrm{ml}$ leptin alone or in combination with $5000 \mathrm{ng} / \mathrm{ml}$ adiponectin for $48 \mathrm{~h}$. Table II shows there were no significant differences in cell cycle distribution in MCF-7 cells between 
Table II. Cell cycle distribution.
(\%) $\mathrm{G} 1 / \mathrm{G} 0$
(\%) G2
(\%) $\mathrm{S}$

\begin{tabular}{lcrr}
\hline MCF-7 & & & \\
0 Control & $79.33 \pm 3.29$ & $15.44 \pm 1.29$ & $8.02 \pm 0.88$ \\
Leptin & $78.13 \pm 3.75$ & $16.53 \pm 1.48$ & $8.61 \pm 0.60$ \\
Leptin+Acrp30 & $81.41 \pm 6.15$ & $9.43 \pm 5.17$ & $9.17 \pm 0.99$ \\
Insulin & $66.82 \pm 1.92$ & $9.45 \pm 0.57$ & $23.72 \pm 2.45$ \\
ANOVA & $\mathrm{P}=0.1003$ & $\mathrm{P}=0.0767$ & $\mathrm{P}<0.0001$
\end{tabular}

T47-D

\begin{tabular}{lccc} 
0 Control & $59.09 \pm 5.38$ & $21.02 \pm 4.32$ & $19.89 \pm 2.93$ \\
Leptin & $60.63 \pm 4.06$ & $18.26 \pm 2.84$ & $21.12 \pm 2.07$ \\
Leptin+Acrp30 & $67.46 \pm 3.17$ & $14.72 \pm 1.87$ & $17.84 \pm 1.30$ \\
Insulin & $48.54 \pm 8.21$ & $17.87 \pm 1.83$ & $33.59 \pm 7.25$ \\
ANOVA & $\mathrm{P}=0.2856$ & $\mathrm{P}=0.7060$ & $\mathrm{P}=0.1004$ \\
\hline
\end{tabular}

Cell cycle distribution of MCF-7 and T47-D cells as determined by flow cytometry. Cells were treated for $48 \mathrm{~h}$ in serum-free medium as described in Materials and methods. Values represent mean \pm standard error of the mean based on 3 replicate experiments for each treatment or control.

leptin-treated, leptin/adiponectin co-treated and untreated cells. Although a similar observation was noted in T47-D cells, a slightly higher proportion of cells in the G1/G0 phase of the cell cycle was observed following adipokine cotreatment compared to untreated or leptin-only treated cells, but this was not statistically significant (Table II).

\section{Discussion}

We have previously evaluated the proliferative response of five human breast cancer cell lines to different concentrations of either leptin or adiponectin $(17,18)$. We found that leptin impacted the enhancement of cell proliferation differently in each line (17) while the anti-proliferative effect of adiponectin also varied (18). Here we now show that the response of these cells to varying ratios of adiponectin:leptin was also different. Overall it appears that the estrogen receptor-positive cell lines were most consistent in being affected by simultaneous exposure to these two adipocytokines at a ratio reflective of an obese individual. Thus these findings would be supportive of results of epidemiological studies suggesting that hormone responsive postmenopausal breast cancer is associated with obesity.

In previous reports on the proliferative effects of leptin on T47-D cells $(15,17)$, we observed significant growth promotion with 50 and $100 \mathrm{ng} / \mathrm{ml}$ leptin treatment of this cell line. We did not see a proliferative effect of leptin in MCF-7 cells at the concentrations used $(5-100 \mathrm{ng} / \mathrm{ml})$; in fact we observed a growth inhibitory effect at 25,50 and $100 \mathrm{ng} / \mathrm{ml}$ leptin in MCF-7 cells after $48 \mathrm{~h}$ (17). This appears to contrast with most reports on the growth response of MCF-7 cells to leptin treatment $(16,22,23)$. It should be noted however, that different investigators utilized different leptin concentrations in their treatment of MCF-7 cells. Dieudonne et al for example used 5-50 nM leptin $(\sim 80-800 \mathrm{ng} / \mathrm{ml})$, and although they did not observe a growth stimulatory effect with the lowest dose $(5 \mathrm{nM}$ or $80 \mathrm{ng} / \mathrm{ml}$ ), significant growth promotion was observed at $20 \mathrm{nM}$ and $50 \mathrm{nM}$ (320 and $800 \mathrm{ng} / \mathrm{ml}$, respectively) (16). These levels are quite high relative to physiological levels found in blood even for obese individuals. Garofalo et al on the other hand, reported a growth stimulatory effect of MCF-7 cells with $100 \mathrm{ng} / \mathrm{ml}$ leptin (22), while Perera et al also recently reported growth stimulation of $\mathrm{MCF}-7$ cells with $500 \mathrm{ng} / \mathrm{ml}$ leptin (23). To our knowledge there are few previous reports on leptin having an inhibitory effect on MCF-7 or other breast cancer cells, besides our earlier report (17), and a report by Oelmann et al who did not detect a growth stimulatory effect of 1-100 ng/ml leptin on HTB-26 (MDA-MB-231) and HTB-131 (MDA-MB-453) breast cancer cells, but in fact observed an inhibitory effect using colony formation experiments (24). The reason for the discrepancy in our result for leptin's effect on MCF-7 cell growth compared to other published reports remains elusive but may lie in the individual molecular characteristics of particular MCF-7 cell lines from different laboratories, culture conditions and the leptin concentrations used.

We also previously reported on the anti-proliferative effects of adiponectin on both T47-D and MCF-7 cell growth (18). From the proliferation assays in the current study, cotreatment of T47-D cells with leptin and adiponectin elicited significant reduction in cell numbers at 25 and $50 \mathrm{ng} / \mathrm{ml}$ leptin in the presence of $5000 \mathrm{ng} / \mathrm{ml}$ adiponectin (Fig. 1B). T47-D cell proliferation was also reduced at the lower leptin concentration of $10 \mathrm{ng} / \mathrm{ml}$ in the presence of $5000 \mathrm{ng} / \mathrm{ml}$ adiponectin, but this was not significant. For MCF-7 cells however, significant growth inhibition was observed at all three leptin concentrations $(10,25$ and $50 \mathrm{ng} / \mathrm{ml})$ in the presence of $5000 \mathrm{ng} / \mathrm{ml}$ adiponectin (Fig. 1A), suggesting these cells are more sensitive to the growth inhibitory effects of adiponectin compared to T47-D cells. This observation was corroborated by our apoptosis data obtained by flow cytometry which indicated that while apoptosis was enhanced with adipokine co-treatment in MCF-7 cells (Fig. 2A), the same co-treatment significantly reduced apoptosis in T47-D cells (Fig. 2B).

In attempting to understand this differential response between T47-D and MCF-7 cells to the adipokine cotreatment, we examined components of the mitogenic/ survival and apoptosis signaling pathways as well as the cell cycle. Specifically, we probed for the presence of the activated forms of the mitogen activated protein kinase (p42/44 MAPK) and agarose kinase target (AKT). In T47-D cells, a more than 3-fold induction of p-p44/42 MAPK was detectable at $48 \mathrm{~h}$ both with leptin treatment alone and with co-treatment with adiponectin, suggesting that this pro-mitogenic pathway involving MAPK was activated in T47-D cells, and that the presence of $5000 \mathrm{ng} / \mathrm{ml}$ adiponectin was not sufficient to mitigate this response (Fig. 3B). In MCF-7 cells only basal levels of p-p42/44 MAPK were detectable at $48 \mathrm{~h}$ (Fig. 3B). This suggests that the p44/42 MAPK pathway was not activated in MCF-7 cells after $48 \mathrm{~h}$ following adipokine cotreatment. We also examined the AKT survival pathway, and it was evident from the Western blot results that these two 
cell lines displayed a differential response to the co-treatment regimen. T47-D cells had more than a 3-fold increase in detectable p-AKT (Thr 308) after $30 \mathrm{~min}$ of co-treatment and the levels of this protein were below basal at $48 \mathrm{~h}$, while detectable levels of this activated form of AKT in MCF-7 cells were 0.3-fold below basal at both time-points (Fig. 3B).

While examining potential mechanisms involved in apoptosis, we observed that while p53 levels were at or below basal within $30 \mathrm{~min}$ following leptin or leptin/adiponectin treatment in T47-D cells, the levels of this tumor suppressor protein, known to promote apoptosis, were more than 4-fold higher in MCF-7 cells following the same treatments at $30 \mathrm{~min}$ (Fig. 3A). Similarly, Bax protein levels were at or below basal in T47-D cells at $30 \mathrm{~min}$, but were almost 2-fold higher in MCF-7 cells 30 min after leptin-only or leptin/adiponectin co-treatment. It is unlikely that the rapid increase in p53 or Bax levels detected in MCF-7 whole cell lysates within 30 min following adipokine treatment resulted from de novo protein synthesis. It is more likely that this transient increase in detectable p53 was the result of a protein complex desequestration mechanism, and would explain the coincident increase in Bax levels since it is well known that p53 can directly activate Bax leading to events that culminate in apoptosis (25). A recent study utilizing homeostatic confocal microscopy elegantly demonstrated the kinetics of Bax protein within minutes in the cytosol of live MCF-7 cells treated with an apoptotic stimulus (26). In that study they suggested the Bax protein accumulation observed in the cytosol within 15 min was likely the result of release of this pro-apoptotic protein from inactivating complexes with other Bcl-2 family members (26). From the foregoing, it seems logical to conclude that the observed increases in detectable Bcl-xL levels within $30 \mathrm{~min}$ of adipokine treatment in both MCF-7 and T47-D cells could also be attributable to a similar de-sequestration mechanism, rather than induction of new protein synthesis within this time interval.

Our flow cytometry apoptosis data revealed that adipokine co-treatment elicited significantly higher apoptosis in MCF-7 cells compared to untreated and leptin-only treated cells (Fig. 2A). An earlier report by Dieudonne et al seems to support the propensity of MCF-7 cells towards apoptosis following adiponectin treatment (19). In that study, they observed inactivation of the MAPK pathway, down-regulation of cyclin D1 and c-myc proteins, a concomitant increase in p53 and Bax mRNA, and a decrease in Bcl-2 mRNA, following treatment with subphysiological levels of adiponectin (25 ng/ml) for $24 \mathrm{~h}(19)$.

Our observations on T47-D cells on the other hand, suggest that these cells were primed for survival following treatment with $50 \mathrm{ng} / \mathrm{ml}$ leptin, and that co-treatment with $5000 \mathrm{ng} / \mathrm{ml}$ adiponectin had a marginal mitigating effect on the mitogenic/ survival pathways (MAPK and AKT) in this cell line. Interestingly, the p42/44 MAPK activation in T47-D cells was sustained even at $48 \mathrm{~h}$ post-treatment (Fig. 3B).

To gain further insight into potential mechanisms by which both cell lines displayed decreased cell proliferation after co-treatment with $50 \mathrm{ng} / \mathrm{ml}$ leptin and $5000 \mathrm{ng} / \mathrm{ml}$ adiponectin, we examined effects on the cell cycle. There were no differences in cell cycle distribution between leptintreated, leptin/adiponectin co-treated and untreated cells in
MCF-7 cells (Table II). We have already noted that in T47-D cells MAPK and AKT pathways were activated and a significantly lower apoptosis rate was observed after cotreatment relative to untreated cells. Furthermore, examination of the cell cycle distribution for T47-D cells did not reveal major differences between leptin-treated, leptin/adiponectin co-treated and untreated cells. However, there was a slightly higher proportion of cells in the G0/G1 phase for adipokine co-treated cells compared to leptin-treated or untreated cells (i.e., $67.5 \%$ vs. 60.6 and $59.1 \%$, respectively), but this was not statistically significant. It is conceivable that apoptosis may yet be activated in T47-D cells co-treated with $50 \mathrm{ng} / \mathrm{ml}$ leptin and adiponectin concentrations $>5000 \mathrm{ng} / \mathrm{ml}$ as was used in this study, since we have previously observed the activation of apoptosis in T47-D cells treated with 1000 $\mathrm{ng} / \mathrm{ml}$ adiponectin in the absence of leptin for $24 \mathrm{~h}$ in serumfree medium by detection of cleaved caspase 8 and PARP (18). Our current results using T47-D cells suggest that the presence of $50 \mathrm{ng} / \mathrm{ml}$ leptin may have been sufficient to obviate the induction of apoptosis in T47-D cells by an adiponectin concentration that was 5 times that we had used previously. Nakayama et al recently reported an inhibitory effect in T47-D cells treated with $0.01-30 \mu \mathrm{g} / \mathrm{ml}$ adiponectin, and this effect was mediated by the inhibition of S-phase cell entry only, without the induction of apoptosis (13). It is unclear what effect the presence of leptin would have had in those experiments. Our current results suggest that growth inhibition with adipokine co-treatment was largely due to apoptosis in MCF-7 cells, with little impact from cell cycle arrest. We also speculate that moderate cell cycle arrest following co-treatment of T47-D cells may provide the explanation for the decrease in cell numbers we observed in the proliferation assays following co-treatment, since apoptosis was actually reduced in this cell line.

There have been few published reports exploring the potential interactions between the adipokines leptin and adiponectin, and how this might impact tumorigenesis in the obese state where leptin levels are elevated and adiponectin levels are reduced. Mistry and colleagues reported on the interaction of leptin and adiponectin in the regulation of prostate cancer cell growth through modulation of p53 and bcl-2 expression (27). In that study the investigators observed a significant growth reduction of the androgen-independent leptin-responsive $\mathrm{PC}-3$ prostate cancer cell line after cotreatment with $100 \mathrm{nM}$ leptin $(\sim 1600 \mathrm{ng} / \mathrm{ml})$ and 1 or $100 \mathrm{nM}$ full length adiponectin $(\sim 28 \mathrm{ng} / \mathrm{ml}$ and $\sim 2.8 \mu \mathrm{g} / \mathrm{ml}$, respectively). In another study using preneoplastic colon epithelial cells (IMCE, Apc ${ }^{\mathrm{Min} /+}$ ) Fenton et al demonstrated adiponectin's ability to block leptin-induced cell signaling and proliferation at concentrations of $0.1,1$ and $10 \mu \mathrm{g} / \mathrm{ml}$ in the presence of $50 \mathrm{ng} / \mathrm{ml}$ leptin. In that study, p44/42 MAPK activation was abrogated by adiponectin treatment in the presence of $50 \mathrm{ng} / \mathrm{ml}$ leptin in these colonic cells (28).

Interestingly, low serum adiponectin levels have been shown to be associated with an increased risk of breast cancer in postmenopausal women $(29,30)$. The relationship of serum leptin to breast cancer on the other hand, has been less conclusive with some published studies indicating an involvement $(31,32)$ while others show no relationship (33-35). Confounding this is the fact that some studies were conducted 
in premenopausal women $(33,36)$ and others in both pre- and postmenopausal women $(31,34,35,37)$ providing at least partial explanation for the ambiguity. However, of particular interest is one study where both serum leptin and adiponectin levels were measured. In that study, postmenopausal women with breast cancer had higher leptin and lower adiponectin levels than control women (21). Additionally, the women diagnosed with breast cancer had an elevated leptin to adiponectin ratio and the higher ratio was associated with more aggressive tumors (21).

Based on the current study and from the other studies cited herein, it seems reasonable to conclude that leptin and adiponectin interact indirectly, and this interaction may have direct effects on the breast cancer risk associated with obesity, where leptin levels are elevated and adiponectin levels are reduced. Our results for the T47-D cell line indicated that growth/survival pathways were activated even in the presence of $5000 \mathrm{ng} / \mathrm{ml}$ adiponectin, a concentration considered a low physiologic level. If elevated leptin by its pro-mitogenic actions portends a higher cancer risk in obesity, it seems plausible to assume that the concurrent decreased adiponectin levels would enhance this risk, due to deficiency in adiponectin's anti-proliferative effects. Thus, the existence of a homeostatic balance between leptin and adiponectin may provide the cellular microenvironment within which normal mammary epithelial cell division and growth occurs. The current results also suggest that the effects of the $\mathrm{A} / \mathrm{L}$ ratio on mediating proliferation may have some specificity since the different cell lines exhibited different responses. This may explain previous inconsistent findings for the relationship of serum measurements with breast cancer. More studies are needed to better understand the complex interactions that exist between these two adipokines.

\section{Acknowledgements}

Funding for this study was provided by The Breast Cancer Research Foundation and The Hormel Foundation.

\section{References}

1. Kirschner MA, Schneider G, Ertel NH and Worton E: Obesity, androgens, estrogens and cancer risk. Cancer Res 42 (Suppl.): S3281-S3285, 1982.

2. Lorincz AM and Sukumar S: Molecular links between obesity and breast cancer. Endocr Relat Cancer 13: 279-292, 2006.

3. Kaur T and Zhang Z: Obesity, breast cancer and the role of adipocytokines. Asian Pacific J Cancer Prev 6: 547-552, 2005.

4. Vona-Davis L and Rose DP: Adipokines as endocrine, paracrine and autocrine factors in breast cancer risk and progression. Endocr Relat Cancer 14: 189-206, 2007.

5. Zhang Y, Proenca R, Maffei M, Barone M, Leopold L and Friedman JM: Positional cloning of the mouse obese gene and its human homologue. Nature 372: 425-432, 1994.

6. Pelleymounter MA, Cullen MJ, Baker MB, Hecht R, Winters D, Boone $\mathrm{T}$ and Collins F: Effects of the obese gene product on body weight regulation in ob/b mice. Science 269: 540-543, 1995.

7. Guzik TJ, Mangalat D and Korbut R: Adipocytokines - novel link between inflammation and vascular function (Review). J Phys Pharm 57: 505-528, 2006.

8. Lago F, Dieguez C, Gomez-Reino J and Gualillo O: Adipokines as emerging mediators of immune response and inflammation (Review). Nat Clin Pract Rheumatol 3: 716-724, 2007.

9. Cleary MP, Phillips FC, Getzin SC, et al: Genetically obese MMTV-TGF alpha/Lep $\left({ }^{\mathrm{ob}}\right) \operatorname{Lep}\left({ }^{\mathrm{ob}}\right)$ female mice do not develop mammary tumors. Breast Cancer Res Treat 77: 205-215, 2003.
10. Cleary MP, Juneja SC, Phillips FC, et al: Leptin receptor deficient MMTV-TGF-alpha/Lepr( $\left.{ }^{\mathrm{db}}\right) \operatorname{Lepr}\left({ }^{\mathrm{db}}\right)$ female mice do not develop oncogene-induced mammary tumors. Exp Biol Med (Maywood) 229: 182-193, 2004.

11. Jarde T, Caldefie-Chezet F, Damez M, Mishellany F, PenaultLlorca F, Guillot J and Vasson MP: Leptin and leptin receptor involvement in cancer development: a study on human primary breast carcinoma. Oncol Rep 19: 905-911, 2008.

12. Dos Santos E, Benaitreau D, Dieudonne MN, Leneveu MC, Serazin V, Giudicelli Y and Pecquery R: Adiponectin mediates an antiproliferative response in human MDA-MB 231 breast cancer cells. Oncol Rep 20: 971-977, 2008.

13. Nakayama S, Miyoshi Y, Ishihara H and Noguchi S: Growthinhibitory effect of adiponectin via adiponectin receptor 1 on human breast cancer cells through inhibition of S-phase entry without inducing apoptosis. Breast Cancer Res Treat 112: 405-410, 2008.

14. Laud K, Gourdou I, Pessemesse L, Peyrat JP and Djiane J: Identification of leptin receptors in human cancer: functional activity in the T47-D breast cancer cell line. Mol Cell Endocrinol 188: 219-226, 2002.

15. Hu X, Juneja SC, Maihle NJ and Cleary MP: Leptin - a growth factor in normal and malignant breast cells and for normal mammary gland development. J Natl Cancer Inst 94: 1704-1711, 2002.

16. Dieudonne MN, Machinal-Quelin F, Serazin-Leroy V, Leneveu MC, Pecquery R and Giudicelli Y: Leptin mediates a proliferative response in human MCF7 breast cancer cells. Biochem Biophys Res Commun 293: 622-628, 2002.

17. Ray A, Nkhata KJ and Cleary MP: Effects of leptin on human breast cancer cell lines in relationship to estrogen receptor and HER2 status. Int J Oncol 30: 1499-1509, 2007.

18. Grossmann ME, Nkhata KJ, Mizuno NK, Ray A and Cleary MP: Effects of adiponectin on breast cancer cell growth and signaling. Br J Cancer 98: 370-379, 2008.

19. Dieudonne M, Bussiere M, Dos Santos E, Leneveu M, Giudicelli Y and Pecquery R: Adiponectin mediates antiproliferative and apoptotic responses in human MCF-7 breast cancer cells. Biochem Biophy Res Comm 345: 271-279, 2006.

20. Grossmann ME, Ray A, Dogan S, Mizuno NK and Cleary MP: Balance of adiponectin and leptin modulates breast cancer cell growth (Letter to the Editor). Cell Res 18: 1154-1156, 2008.

21. Chen DC, Chung YF, Yeh YT, Chaung HC, Kuo FC, Fu OY, Chen HY, Hou MF and Yuan SS: Serum adiponectin and leptin levels in Taiwanese breast cancer patients. Cancer Lett 237: 109-114, 2006.

22. Garofalo C, Sisci D and Surmacz E: Leptin interferes with the effects of the antiestrogen ICI 182,780 in MCF-7 breast cancer cells. Clin Cancer Res: 6466-6475, 2004.

23. Perera CN, Spalding HS, Mohammed SI and Camarillo IG: Identification of proteins secreted from leptin stimulated MCF-7 breast cancer cells: a dual proteomic approach. Exp Biol Med (Maywood) 233: 708-720, 2008.

24. Oelmann E, Haghu S, Kulimova E, Serve H, Schmitmann C and Berdel W: Correspondence Re: Leptin - a growth factor in normal and malignant breast cells for normal mammary gland development. J Natl Cancer Inst 95: 1171-1173, 2003.

25. Chipuk, JE, Kuwana T, Bouchier-Hayes L, Droin NM, Newmeyer DD, Schuler M and Green DR: Direct activation of Bax by p53 mediates mitochondrial membrane permeabilization and apoptosis. Science 303: 1010-1014, 2004.

26. Godlewski MM, Gorka M and Lamparska-Przybysz M: Minute kinetics of proapoptotic proteins: Bax and Smac/Diablo in living tumor cells revealed by homeostatic confocal microscopy. Cytotechnology 45: 141-153, 2004.

27. Mistry T, Digby JE, Desai KM and Randeval HS: Leptin and adiponectin interact in the regulation of prostate cancer cell growth via modulation of $\mathrm{p} 53$ and bcl-2 expression. BJU Int 101: 1317-1322, 2008

28. Fenton JI, Birmingham JM, Hursting SD and Hord NG: Adiponectin blocks multiple signaling cascades associated with leptin-induced cell proliferation in $\mathrm{Apc}^{\mathrm{Min} /+}$ colon epithelial cells. Int J Cancer 122: 2437-2445, 2008.

29. Miyoshi Y, Funahashi T, Kihara S, Taguchi T, Tamaki Y, Matsuzawa Y and Noguchi S: Association of serum adiponectin levels with breast cancer risk. Clin Cancer Res 9: 5699-5704, 2003.

30. Mantzoros C, Petridou E, Dessypris N, Chavelas C, Dalamaga M, Alexe DM, Papadiamantis Y, Markopoulos C, Spanos E, Chrousos G and Trichopoulos D: Adiponectin and breast cancer risk. J Clin Endocrinol Metab 89: 1102-1107, 2004. 
31. Ozet A, Arpaci F, Yilmaz MI, Ayta H, Ozturk B, Komurcu S, Yavuz AA, Tezcan Y and Acikel C: Effects of tamoxifen on the serum leptin level in patients with breast cancer. Jpn J Clin Oncol 31: 424-427, 2001.

32. Liu CL, Chang YC, Cheng SP, Chern SR, Yang TL, Lee JJ, Guo IC and Chen CP: The roles of serum leptin concentration and polymorphism in leptin receptor gene at codon 109 in breast cancer. Oncology 72: 75-81, 2007.

33. Mantzoros CS, Bolhke K, Moschos S and Cramer DW: Leptin in relation to carcinoma in situ of the breast: a study of premenopausal cases and controls. Int J Cancer 80: 523-526, 1999.

34. Petridou E, Papadiamantis Y, Markopoulos C, Spanos E, Dessypris $\mathrm{N}$ and Trichopoulos D: Leptin and insulin growth factor I in relation to breast cancer (Greece). Cancer Causes Control 11: 383-388, 2000.
35. Woo HY, Park HY, Ki CS, Park YL and Bae WG: Relationships among serum leptin, leptin receptor gene polymorphisms, and breast cancer in Korea. Cancer Lett 237: 137-142, 2006.

36. Falk RT, Brinton LA, Madigan MP, Potischman N, Sturgeon SR, Malone KE and Daling JR: Interrelationships between serum leptin, IGF-1, IGFBP3, C-peptide and prolactin and breast cancer risk in young women. Breast Cancer Res Treat 98: 157-165, 2006.

37. Sauter ER, Garofalo C, Hewett JE, Morelli C and Sumarcz E: Leptin expression in breast nipple aspirate fluid (NAF) and serum is influenced by body mass index (BMI) not by the presence of breast cancer. Horm Metab Res 36: 336-340, 2004. 